\title{
誘導結合高周波プラズマ支援マグネトロンスパッタによる 光学多層膜フィルタの作製と二酸化炭素濃度検出への応用*
}

\author{
原化*1 $\cdot$ 岸直輝*1
}

（受理2000年 9 月 8 日，掲載決定2001年12月 2 日）

\begin{abstract}
Micro Variable Infrared Filter using Magnetron Sputtering System Enhanced with an Inductively Coupled RF Plasma for $\mathrm{CO}_{2}$ Measurement
\end{abstract}

\author{
Hitoshi HARA*1 and Naoki KISHI*1 \\ ${ }^{* 1}$ Micromachining Laboratory, Yokogawa Electric Corporation \\ 2061 Miyada-mura, Kamiina-gun, Nagano Prefecture, 399-4394 Japan
}

(Received September 8, 2000, Accepted December 2, 2000)

\begin{abstract}
We have developed a micro variable infrared filter using a magnetron sputtering system enhanced with inductively coupled RF plasma, and have demonstrated $\mathrm{CO}_{2}$ concentration measurement using silicon micro bolometers and the filter as a Non-Dispersive Infra-Red (NDIR) system. The micro variable infrared filter was tuned to two different wavelengths, on and off the $\mathrm{CO}_{2}$ absorption band at $4.3 \mu \mathrm{m}$. By combining the NDIR sysytem with a conventional infrared source, concentration of $\mathrm{CO}_{2}$ could be measured in a range of $1000-5000 \mathrm{ppm}$, with a reproducibility of $\pm 3.6 \%$ $(3 \sigma)$ of the measured values.
\end{abstract}

\section{1. はじめに}

近年, 屋内の空気の清净度の目安として二酸化炭素濃 度の測定が注目されている.二酸化炭素の濃度は, 室内 の人数や設備などの使用状況に応じた環境保全（高濃度 では意識障害が発生するため, 濃度上限を $1000 \mathrm{ppm}$ 以 下に設定）と，省エネルギーに配虑した最適な換気コン トロールの指標となる．二酸化炭素濃度の測定方法とし て，従来型の赤外分光法は，波長を限定した多層膜干渉 フィルタ方式1)，回折格子を分散素子とした回折格子方 式1)，干渉を利用したフーリエ変換赤外分光 (FT-IR) 方式 2,3 と大別される。参照用ガスセルと測定用ガスセ ルを用いるダブルビーム方式では測定装置が大きくな り, 一方, シングルビームでは複数の波長選択フィルタ を切り替光る機構や，ギャップ長可変のファブリーペロ

\footnotetext{
* 平成12年 5 月 12 日 日本真空協会スパッタリング・プラズマプロセス 研究部会で講演

*1 横河電機株式会社マイクロマシン研究室（开399-4394 長野県上伊那 郡宮田村2061)
}

ーフィルタなどの可動部品が必要であった。これらの課 題の解決に向け，マイクロ赤外分析デバイスの有効性が 認識されるようになっている. 我々は各方式を小型化す る時に生じる分解能の優劣について比較を行い, マイク 口化に有利な方式を検討した. 回折格子方式と FT-IR 方式ではマイクロ化に伴って分解能が低下寸るのに対し て，多層膜干渉フィルタ方式では分解能が低下しないた め, サイズ $1 \mathrm{~cm}$ 以下では 3 つの分光方式の分解能は 10 $\mathrm{nm} \sim 100 \mathrm{~nm}$ の同様な範囲に入っている. 光学系の複雑 さなどを考慮すると，多層膜干渉フィルタ方式 ${ }^{4,5)}$ は実 現性が高く, マイクロ化に打いて発展性が高いことが判 明し，マイクロ波長可変赤外フィルタ6,7)と $\mathrm{Si}$ マイク口 ボロメータ 8-11)を組み合わせたマイクロ赤外分析デバイ ス（Fig. 1）を提案している. マイクロ波長可変赤外フ ィルタは多層膜干渉フィルタの中間層の膜厚を位置によ って変化させることで透過位置によって中心波長が異な る性質を有する。 


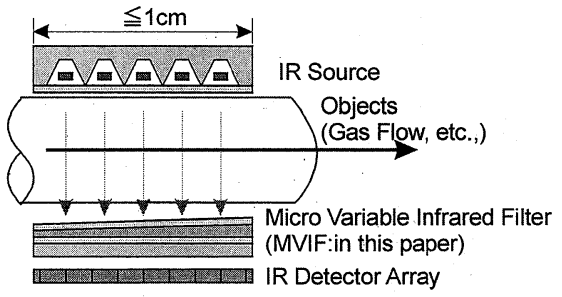

Fig. 1 Schematic diagram of the micro infrared spectroscope.

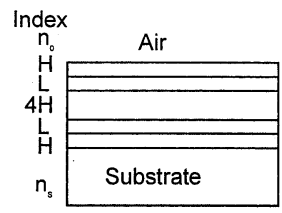

$\lambda / 4$ type multiple layers $=\lambda / 2$ type spacer layer ] $\lambda / 4$ type multiple layers Air/(HL)/4H/(LH)/Substrate $\mathrm{H}$ : High Refractive Index Layer $L$ : Low Refractive Index Layer

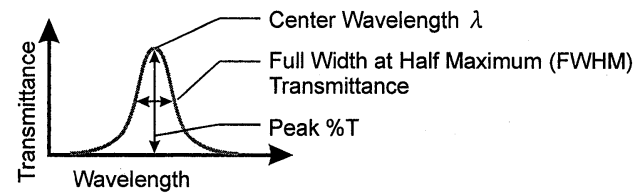

Fig. 2 SHW type filter cross-section (Five Layers).

\section{2. マイクロ波長可変赤外フィルタの成膜装} 置

マイクロ波長可変赤外フィルタを多層膜干渉フィルタ で実現するために必要な成膜条件から，マイクロ波長可 変赤外フィルタ形成用成膜装置の成膜誤差がフィルタ透 過特性に与える影響を検討した. 成膜時の膜厚誤差が括 よぼす透過特性への影響を検討するための条件として，

Fig. 2 のように膜構造が簡単な, スペーサ層が 1 つの SHW (Single Half-Wave) 型フィルタである中心波長 2 $\mu \mathrm{m}$ の 5 層フィルタを仮定し, 高屈折率物質としてシリ コン $(\mathrm{Si}, \mathrm{H}$ 層 $)$, 低屈折率物質として酸化シリコン $\left(\mathrm{SiO}_{2}, \mathrm{~L}\right.$ 層)，膜構成は

ガラス基板/HL $(4 \mathrm{H}) \mathrm{LH} /$ 空気

を想定した. 光学薄膜シミュレーション (OPTASFILM）より，透過特性の変化に最も大きく影響を与え るのはスペーサ層の膜厚ずれであり, 全層で+2\%膜厚 ずれが生じた場合の中心波長ずれは， $\Delta \Lambda=+2 \%$ とな ることがわかった. 成膜装置に要求される膜厚 $\mathrm{d}$ に対 する膜厚誤差 $\Delta d$ の仕様は, $\Delta d / d \leqq \Delta \lambda / \lambda$ の式から求め られる. マイクロ光分析デバイスの 2 $10 \mu \mathrm{m}$ 波長帯域 の分割数を100（波長領域幅 $8 \mu \mathrm{m} /$ 分解能 $80 \mathrm{~nm}=100$ ) とすると，中心波長ずれの許容範囲が土 $40 \mathrm{~nm}$ となり，

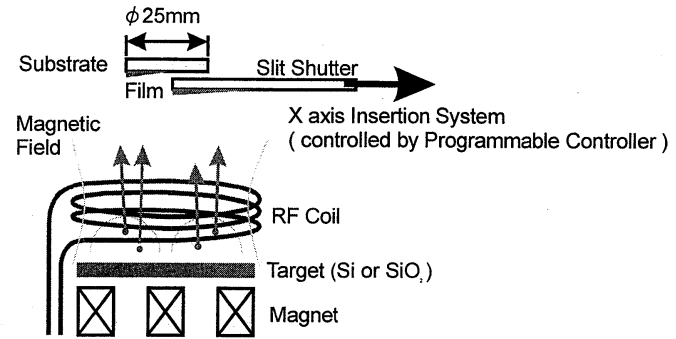

Fig. 3 Schematic diagram of the magnetron sputtering source enhanced with an inductively coupled $\mathrm{rf}$ plasma and the slit shutter system.

成膜装置の膜厚誤差は土 $2 \%$ 以下が必要になる．膜厚誤 差が $2 \%$ 以下で多層膜が成膜可能な装置として, 誘導 結合高周波プラズマ支援マグネトロンスパッタ装置（以 下ヘリコンスパッタ装置と略) ${ }^{12)}$ に多層膜の成膜が可能 な機構と, 膜厚を傾斜させるためのシャッター機構を付 加して, 成膜性能を評価した.

\section{1 ヘリコンスパッタ装置の成膜原理}

ヘリコンスパッタ装置の成膜原理の概略を Fig. 3 に 示す. 磁場と平行に電磁波が進むとき, その電磁波の右 回りの円偏向波と同じ方向に運動するプラズマ中の電子 が結合して発生するへリコン波領域 $(2 \mathrm{MHz} \sim 1 \mathrm{GHz})$ では, 波の速度とプラズマ中の電子の速度が熱速度の大 ささとほぼ同じで, 波のエネルギーが効率よくプラズマ に伝わり, 高密度なプラズマが得られる. この原理をス パッタリング装置に応用すると, 成膜効率が高く, 不純 物や 2 次生成物が少ないため膜質がよく, 膜厚の均一性 が高いため, 本研究でマイクロ波長可変赤外フィルタを 形成するための装置に適している.

\section{2 仕様}

マイクロ波長可変赤外フィルタ形成用成膜装置に要求 される仕様を以下に示す.

- 成膜面内膜厚分布 : $\pm 2 \%$ 以下 ( $\phi 25 \mathrm{~mm}$ 範囲内)

-成膜速度 : $1 \mathrm{~nm} / \mathrm{min}$ 以上

- 基板サイズ : 最大 $\phi 100 \mathrm{~mm}$

- 基板加熱温度 : $200^{\circ} \mathrm{C} \sim 500^{\circ} \mathrm{C}$

・傾斜薄膜作製用シャッター：基板中心部 $\phi 25 \mathrm{~mm}$ の 範囲内で往復運動が可能

・カソード : 非磁性用カソード 2 式（高屈折率物質, 低屈折率物質）

これらの仕様を満たすために，ヘリコンスパッタリング 装置に多層膜の成膜が可能な機構と, 膜厚を傾斜させる ためのシャッター機構を付加したマイクロ波長可変赤外 フィルタ形成用成膜装置を導入した. 


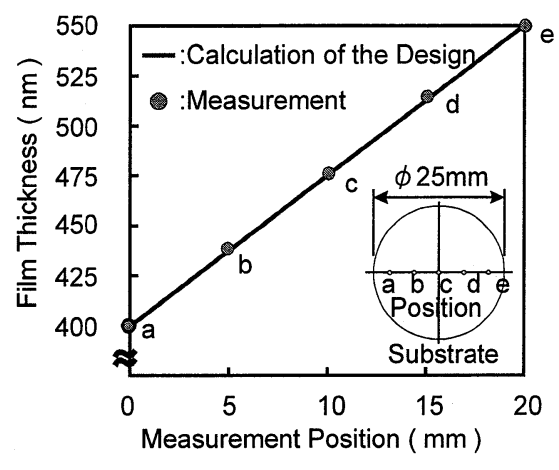

Fig. 4 Relationship of the film thickness and measurement position.

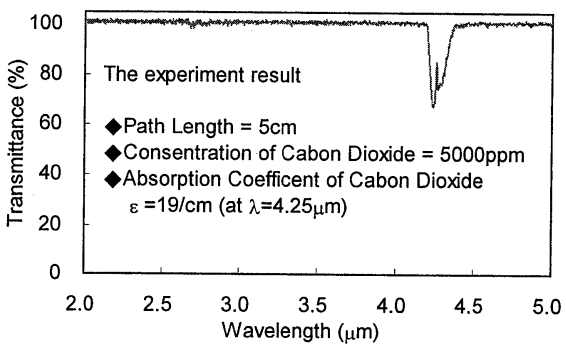

Fig. 5 Observation of the absorption band of carbon dioxide.

\section{3 成膜性能実験結果}

成膜性能の例として, 薄膜材料である $\mathrm{Si}$ と $\mathrm{SiO}_{2}$ を成 膜して得られた傾斜膜厚の均一性を Fig. 4 亿示す. 基 板には直径 $\phi 25 \mathrm{~mm}$ の $\mathrm{Si}$ 基板とガラス基板を用いた。 測定点は, Fig. 4 亿示す $\phi 25 \mathrm{~mm}$ の範囲内の 5 点で, 設 計膜厚に対していずれも $1 \%$ 以下の良好な成膜性能が 得られた。また, 酸化チタン $\left(\mathrm{TiO}_{2}\right)$ とゲルマニウム （Ge）飞执いても同様の結果を得た。単層膜で面内膜厚 誤差土1\%が確認された。

\section{3. マイクロ波長可変赤外フィルタの設計と 作製}

多層膜の干渉を利用した狭帯域透過フィルタとして， 誘電体多層膜による簡単な SHW 型フィルタ（Fig. 2) を用いた。多層膜構成は $(\lambda / 4$ 型多層膜 $)(\mathrm{m} \times \lambda / 2$ 型中 間層) $(\lambda / 4$ 型多層膜）である. $\mathrm{m}$ は整数である。透過 中心波長を $\lambda$, 屈折率を $n$, 膜厚を $d$ とすると, $n d=\lambda$ I 4 の条件を満たす高屈折率物質と低屈折率物質を交互に 積層したものが $\lambda / 4$ 型多層膜である.

一方, 中間層は高屈折率物質の層であり, この層の及 の膜厚の変化によって, 波長 $\lambda$ の近傍の限られた範囲

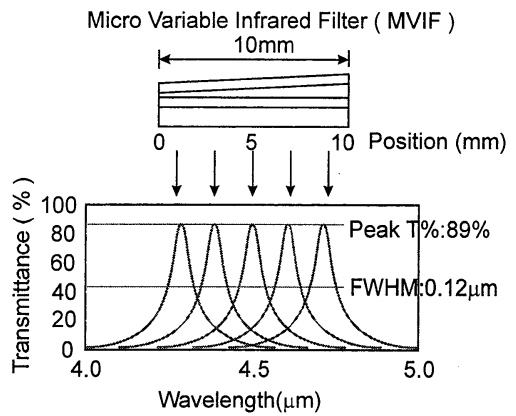

Fig. 6 Relationship between spacer thickness and transmission characteristics caluculated by the thin film optical simulation (OPTAS FILM).

内で，透過中心波長を变化させることができる，従っ て，定められた位置に対応するように中間層の膜厚を制 御することにより, 複数の波長が選択できるマイクロ波 長可変赤外フィルタが構成できる. その制御は，マイク 口波長可変赤外フィルタ形成用成膜装置に付加した直線 導入式シャッター機構によって, 成膜中にハードマスク をかけることで可能となり, 精密制御傾斜型薄膜扣よび 精密制御階段型薄膜が作製できる.

\section{1 マイクロ波長可変赤外フィルタの設計}

Fig. 5 亿示すように $4.18 \sim 4.46 \mu \mathrm{m}$ の範囲に二酸化炭 素の特性吸収帯が存在し, $4.24 \mu \mathrm{m}$ 之 $4.27 \mu \mathrm{m}$ の 2 つの ピークもつ.ここでは, 後述のフィルタの半值幅に関す る考察に基づき，二酸化炭素検出用の中心波長を 4.25 $\mu \mathrm{m}$, 半值幅を $0.12 \mu \mathrm{m}$, ベースライン補正用の中心波 長を $3.80 \mu \mathrm{m}$ に設定し，この両者が同一基板上の $5 \mathrm{~mm}$ 離れた位置で得られるマイクロ波長可変赤外フィルタを 設計する. SHW 型 5 層狭帯域フィルタの中間層のみの 膜厚を変化させることによって，フィルタ内の透過位置 によって中心波長を可変する.

サファイア基板に，5層多層膜 $\mathrm{HL}(4 \mathrm{H}) \mathrm{LH}$ を成膜 し, 中間層 $4 \mathrm{H}$ はフィルタ内の位置によって $3.80 \mu \mathrm{m}$ と $4.25 \mu \mathrm{m}$ の中心波長が得られるよらに膜厚を変化させ る. 光学薄膜シミュレーションによる設計結果を Fig. 6, Table 1 亿示寸. 基板は, 厚さ $0.5 \mathrm{~mm}$ のサファイア 基板を用いたが，フィルタとの整合層和よび裏面反射防 止層の 2 層を付加した $\mathrm{Si}$ 基板でも作製可能である.

\section{2 マイクロ波長可変赤外フィルタの作製}

試作した素子を Fig. 7 亿示す. 成膜条件は，基板温 度 $200^{\circ} \mathrm{C}$, 基板ターゲット距離 $200 \mathrm{~mm}$, 成膜レートはシ リコン $4.3 \mathrm{~nm} / \mathrm{min}$ ，シリコン酸化膜 $1.2 \mathrm{~nm} / \mathrm{min}$ であ る. 中間層を成膜するときは，参照用の中心波長となる $3.80 \mu \mathrm{m}$ に相当するシリコンの膜厚まではシャッターを 開放し，その後に基板の半分を覆い隠すようにシャッタ 
Table 1 Design of micro variable infrared filter

\begin{tabular}{l|c|c|c|c}
\hline \hline $\begin{array}{c}\text { Layer } \\
\text { No. }\end{array}$ & Material & $\begin{array}{c}\text { Refractive } \\
\text { Index } \\
(n)\end{array}$ & $\begin{array}{c}\text { Thickness } \\
(d) \\
{[\mathrm{nm}]}\end{array}$ & $\begin{array}{c}\text { Deposited } \\
\text { Rate } \\
{[\mathrm{nm} / \mathrm{min}]}\end{array}$ \\
\hline Substrate & Sapphire & 1.6 & 500000 & \\
\hline $1(\mathrm{H})$ & Silicon & 3.9 & 272 & 4.35 \\
\hline $2(\mathrm{~L})$ & Silicon Dioxide & 1.6 & 670 & 1.35 \\
\hline $3(4 \mathrm{H})$ & Silicon & 3.9 & $970-1100$ & 4.35 \\
\hline $4(\mathrm{~L})$ & Silicon Dioxide & 1.6 & 670 & 1.35 \\
\hline $5(\mathrm{H})$ & Silicon & 3.9 & 272 & 4.35 \\
\hline
\end{tabular}

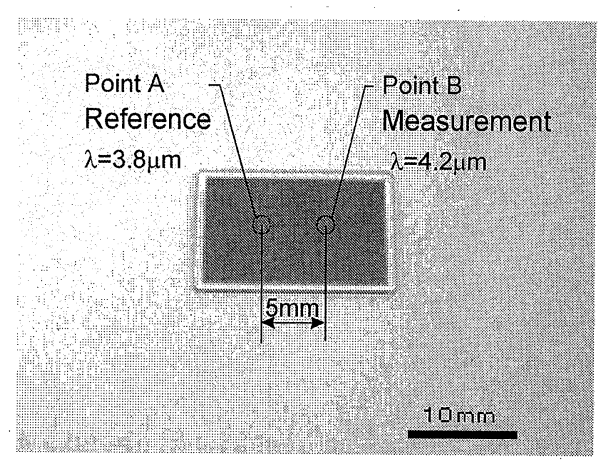

Fig. 7 Micro variable infrared filter.

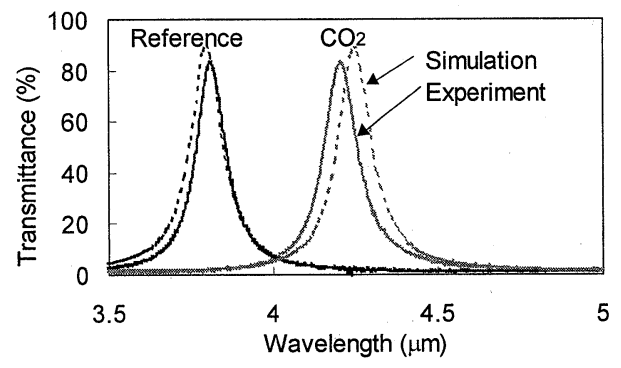

Fig. 8 Spectral transmission characteristics of micro variable infrared filter.

一を移動して測定用の中心波長となる $4.25 \mu \mathrm{m}$ に相当す るシリコン膜厚になるまで成膜した.

\section{4. マイクロ波長可変赤外フィルタの分光特 性評価}

試作したマイクロ波長可変赤外フィルタの $5 \mathrm{~mm}$ 離れ た位置の分光特性を自記式分光光度計によって評価した 結果を, 設計した分光特性と比較して Fig. 8 と Table 2 に示す. 二酸化炭素による吸収を測定するフィルタの 中心波長は, 設計より $0.05 \mu \mathrm{m}$ 短波長側にシフトして作 製されたが，Fig. 5 の二酸化炭素吸収特性から許容され る中心波長の誤差は $\pm 0.05 \mu \mathrm{m}$ であるため, 感度低下は
Table 2 Spectrum transmission characteristics of micro variable infrared filter

\begin{tabular}{c|c|c|c|c|c|c}
\hline & \multicolumn{2}{|c|}{$\begin{array}{c}\text { Center } \\
\text { Wavelength } \\
(\mu \mathrm{m})\end{array}$} & \multicolumn{2}{c|}{$\begin{array}{c}\text { Peak } \\
\text { Transmittance } \\
(\%)\end{array}$} & \multicolumn{2}{|c|}{$\begin{array}{c}\text { Full Width at } \\
\text { Half Maximum } \\
(\mu \mathrm{m})\end{array}$} \\
\cline { 2 - 7 } & $\begin{array}{c}\text { Simu- } \\
\text { lation }\end{array}$ & $\begin{array}{c}\text { Exper- } \\
\text { iment }\end{array}$ & $\begin{array}{c}\text { Simu- } \\
\text { lation }\end{array}$ & $\begin{array}{c}\text { Exper- } \\
\text { iment }\end{array}$ & $\begin{array}{c}\text { Simu- } \\
\text { lation }\end{array}$ & $\begin{array}{c}\text { Exper- } \\
\text { iment }\end{array}$ \\
\hline $\begin{array}{c}\text { Reference } \\
(\text { Point A) }\end{array}$ & 3.80 & 3.81 & 89 & 83 & 0.12 & 0.11 \\
\hline $\begin{array}{c}\text { Measurement } \\
(\text { Point B })\end{array}$ & 4.25 & 4.20 & 89 & 83 & 0.12 & 0.12 \\
\hline
\end{tabular}

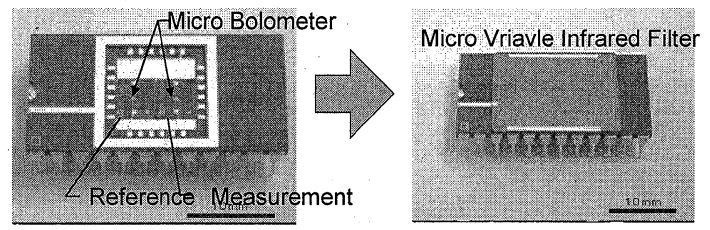

Fig. 9 Assembly of two bolometers and micro variable infrared filter.

生じない，透過率は設計より $6 \%$ 低下したが，赤外検出 素子の $\mathrm{S} / \mathrm{N}$ は十分確保できる. 以上の結果より, 試作 したフィルタの分光特性は設計に対して許容誤差内にあ ることを確認した．基板の中心で階段状に中間層の膜厚 を変化させたため，膜厚が変化している境界では分光特 性が近接する 2 つ波長を重ね合わせた特性になる。フ ィルタ上の波長の分離境界の幅は $1 \mathrm{~mm}$ になる.

\section{5. マイクロ光分析デバイスへの応用}

2つの Si マイクロボロメータ, マイクロ波長可変赤 外フィルタ, 赤外光源 (ION Optics Inc. 製) を用いて, 二酸化炭素検出用の分析デバイスの実証モデルを組立 て, 二酸化炭素の標準ガスの濃度を変化させて動作確認 を行った. 光路長 $50 \mathrm{~mm}$ の一方にサファイア空付の赤 外光源, も5一方に 2 つの $\mathrm{Si}$ マイクロボロメータの上 にマイクロ波長可変赤外フィルタを取り付けたパッケー ジ（Fig. 9）とワイドバンドパスフィルタを取り付けた ガスセルの組み合わせで実証モデル（Fig. 10）を試作 し, 濃度5060 ppm の二酸化炭素標準ガスと窒素ガスを 毛細管式流量比混合法を用いた標準ガス分割器 (STEC 製）で 5 種類の濃度に調整して，ガスセル内に $500 \mathrm{cc} /$

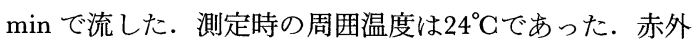
光源は矩形波変調 $\left(5 \mathrm{~Hz}, 10 \%\right.$ Duty Cycle, $500^{\circ} \mathrm{C}$, 電力 $0.7 \mathrm{~W}_{\mathrm{p-p}}$ ) で赤外発光している. 矩形波変調された赤外 光信号は, ボロメータの抵抗值をブリッジ回路で電圧変 化信号として取り出し， ロックインアンプで増幅して検 出する. 評価に用いたボロメータは, $5 \mathrm{~Hz}$ の赤外光が 


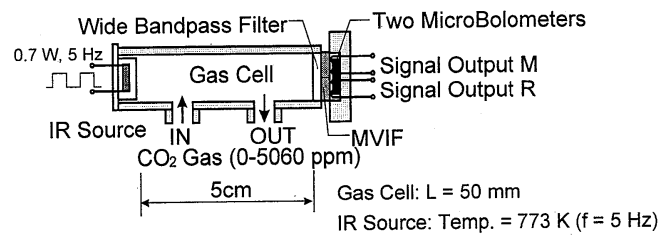

Fig. 10 Schematic diagram of the protopype $\mathrm{CO}_{2}$ sensor.

検出できるように遮断周波数を $10 \mathrm{~Hz}$ で設計し, $\mathrm{Si}$ マイ クロマシン加工で作製した：二酸化炭素の濃度を 0 ppm および, 1012 ppm, 2024 ppm, 3036 ppm, 4048 ppm, $5060 \mathrm{ppm}$ の 5 種類に変化させて参照用 $\mathrm{Si}$ マイクロボロ メータの信号出力 $\mathrm{R}$ と測定用 $\mathrm{Si}$ マイクロボロメータの 信号出力 $\mathrm{M}$ を測定し，信号出力比 $\mathrm{M} / \mathrm{R}$ を求めた。濃 度 $0 \mathrm{ppm}$ のときの $\mathrm{M} / \mathrm{R}$ で規格化した信号変化量 $\Delta \mathrm{M} /$ $\mathrm{R}$ と二酸化炭素の濃度の関係を Fig. 11に示す. グラフ 中の記号 $(O \triangle \square \times)$ は 4 回の測定データを示している.

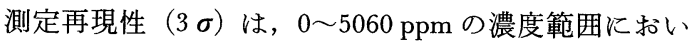
て測定值の士3.6\%以下であることを確認した．測定バ ラッキの原因としては，パッケージを含む測定回路ノイ ズ，フィルタの半值幅が広いことによるベースライン変 動の影響などが考学られる. Fig. 9 と同様に，ハーメチ ックシールパッケージのステム（TO-5）に2つの $\mathrm{Si}$ マ イクロボロメータ取り付けて, 真空中でマイクロ波長可 変赤外フィルタを取り付けたキャップを封止することに よって測定回路ノイズが低減し，測定バラッキが約 $1 / 2$ に減少した．その他の測定バラッキの原因に関しては, 今後の研究課題である。

\section{6. ま と め}

膜厚を傾斜できる機構を付加したへリコンスパッタ装 置を用いて，同一基板上の $5 \mathrm{~mm}$ 間隔で二酸化炭素検出 用と参照光用の波長が選択でさるマイクロ波長可変赤外 フィルタを作製し，2つの $\mathrm{Si}$ マイクロボロメータとの 組み合わせによって, 光源変動や光学系の污れなどが補 正できる 2 光路 2 波長比較 NDIR 方式で二酸化炭素の 濃度を測定でさる実証モデルを評価した．二酸化炭素濃 度の測定再現性は $3 \sigma$ で測定值 $\pm 3.6 \%$ 以下であること を確認し，マイクロ光分析デバイスの基本動作を実証し た. 本報告では, 中間層の膜厚を階段状に変えた 2 波長 のフィルタについて述べたが，中間層の膜厚を傾斜（連 続的に変化）させたフィルタとボロメータアレイを組み 合わせることによって測定精度の向上が期待できる.

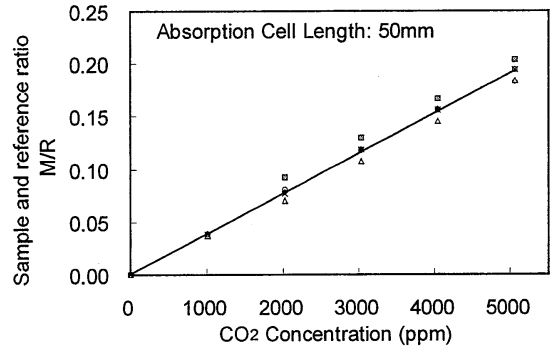

Fig. 11 Result of the $\mathrm{CO}_{2}$ concentration measurement.

\section{謝辞}

本研究は, 通産省工業技術院の産業科学技術研究開発 制度に基づく「マイクロマシン技術の開発」の一環とし て, NEDOから委託を受けた(財)マイクロマシンセンタ 一の再委託業務として横河電機(侏)が実施したものであ る.

\section{[文献]}

1）岩本睦夫, 河野澄夫, 魚住 準 : “近赤外分光法入 門”，幸書房, 1994, pp. 97-101.

2）岩本睦夫，河野澄夫，魚住 準 : “近赤外分光法入 門”，幸書房, 1994, pp. 128 .

3）田中誠之, 寺前紀夫 : “赤外分光法”, 共立出版, 1993, pp. 24-40.

4) Optical Coating Laboratory Inc. (OCLI), "Stock Products Catalog', 1994, Vol. 5.

5) James D. Rancourt: “Optical Thin Films Users Handbook”, McGraw-Hill, Inc. 1987.

6) Hitoshi Hara: "Micro Variable Infrared Filter", Trans. IEE of Japan, Vol. 119-E, No. 2, Feb., 1999, pp. 99-102.

7）原 亡，他：“ヘリコンスパッタリングによる透 過波長可変赤外フィルタの製作”, 第46回応用物理学 関係連合講演会講演予稿集, No. 3, March, 31, 1999, pp. 1041.

8）岸 直輝，他：“SOI 基板を用いた非冷却マイク ロボロメータ”, 第46回応用物理学関係連合講演会講 演予稿集, No. 1, March, 30, 1999, pp. 490.

9) Naoki Kishi:"Micro Bolometer of Single Crystal Silicon', IMEKO-XV, Jun, 16, 1999.

10）原仁：“SOI 基板を用いた非冷却マイクロボ ロメータ”，平成11年度電気学会センサマイクロマシ ソ準部門総合研究会, November, 12, 1999.

11）原卡：“高濃度ドープシリコンの赤外吸収特性 とマイクロボロメータへの適用”, 平成12年電気学会 全国大会, March, 21, 2000.

12）松浦正道, 他：“高イオン化スパッタ法としてのへ リコンスパッタの放電执よび膜特性”, ULVAC Techical Journal, No. 47, 1997. 